\title{
PACIENTE SEM REALIZAÇÃO DE DIÁLISE PERITONEAL COM PERITONITE EOSINOFÍLICA.
}

\author{
Jana Lucia Borges ${ }^{1}$, Janaína Porto Wegner¹, Letícia Bastos \\ Schroder ${ }^{1}$, Lilian Missio ${ }^{1}$, Carlos Daniel Hernandez Antonello², \\ Rosilene Jara Reis ${ }^{3}$.
}

${ }^{1}$ Acadêmicas do Curso de Medicina da ULBRA, Canoas/RS. ${ }^{2}$ Médico Cirurgião Oncológico.

${ }^{3}$ Médica Ginecologista Obstetra e Cirurgiã Oncológica. Professora da Disciplina de Ginecologia e Obstetrícia do Curso de Medicina da ULBRA, Canoas/RS.

\section{Resumo}

INTRODUÇÃO: Peritonite eosinofílica é entendida como uma

complicação que ocorre mais frequentemente em pacientes submetidos a diálise peritoneal, geralmente dentro dos três primeiros meses de início do procedimento e afeta crianças e adultos. É definida através de exames do líquido peritoneal com contagem de glóbulos brancos $>100$ células $/ \mathrm{ml}$ e com $\geq 10 \%$ de eosinófilos. Possui fisiopatologia pouco compreendida, onde acredita-se que esteja relacionada com reação de hipersensibilidade aos materiais e fluidos usados durante o processo de diálise, e correlação com bactérias ou fungos $1,2,3$.

METODOLOGIA: Trata-se de um relato de caso

RELATO DE CASO: Paciente L.H, feminina, 52 anos, branca, casada, empresária do ramo de alimentos. Previamente hígida, sem cirurgias prévias, sem uso de medicação contínua. Apresenta quadro de distensão abdominal, náuseas, êmese de conteúdo fecalóide, acompanhados de dor difusa em abdome, sem fator de alívio ou agravo e sem posição antálgica. Apresenta-se constipada sem eliminação de flatos. 
Ao exame físico estava lúcida, orientada, consciente, em regular estado geral. Hipocorada, desidratada. Ruidos hidroaéreos diminuídos. Abdome distendido e com defesa a palpação.

Na suspeita de suboclusão intestinal, é realizado tratamento conservador. Evolui com piora do leucograma e importante distensão do intestino delgado em exame tomográfico.

Realizado procedimento cirúrgico de laparotomia, é identificado quadro de peritonite com ausência de local definido de obstrução intestinal e ausência de foco infeccioso. Identificado membrana de aspecto mucóide junto ao peritônio parietal do intestino delgado.

Ao exame anatomopatológico é confirmado o diagnóstico de peritonite eosinofílica. Evolui após quinto e sétimo dia pós-operatório com alta.

CONCLUSÃO: As peritonites são as complicações mais comuns de diálise peritoneal e as mais graves por influenciar na morbidade e mortalidade dos pacientes. ${ }^{4,5}$ As peritonites com cultura negativa correspondem a $10 \%$ das peritonites e a eosinofílica se enquadra nesse grupo e apresentam quadro e desfecho favoráveis. ${ }^{5}$

A peritonite eosinofílica, dessa forma, é um tipo raro, a qual acontece geralmente secundária a bactérias, fungos ou infecção tuberculosa ou como uma reação a medicamentos intraperitoneal ou componentes do sistema de diálise como tubulações ou solução. ${ }^{4}$

Para tanto, é importante estar atento aos possíveis diagnósticos diferenciais dessa patologia, tais como abdome agudo inflamatório, neoplasias, outras peritonites e aderências para o manejo adequado do paciente. 
